\title{
Measurement of Flow Pattern Within a Rotating Stall Cell in an Axial Compressor
}

Jan Lepicovsky

QSS Group Inc., Cleveland, Ohio

Edward P. Braunscheidel

Glenn Research Center, Cleveland, Ohio 


\section{NASA STI Program . . . in Profile}

Since its founding, NASA has been dedicated to the advancement of aeronautics and space science. The NASA Scientific and Technical Information (STI) program plays a key part in helping NASA maintain this important role.

The NASA STI Program operates under the auspices of the Agency Chief Information Officer. It collects, organizes, provides for archiving, and disseminates NASA's STI. The NASA STI program provides access to the NASA Aeronautics and Space Database and its public interface, the NASA Technical Reports Server, thus providing one of the largest collections of aeronautical and space science STI in the world. Results are published in both non-NASA channels and by NASA in the NASA STI Report Series, which includes the following report types:

- TECHNICAL PUBLICATION. Reports of completed research or a major significant phase of research that present the results of NASA programs and include extensive data or theoretical analysis. Includes compilations of significant scientific and technical data and information deemed to be of continuing reference value. NASA counterpart of peer-reviewed formal professional papers but has less stringent limitations on manuscript length and extent of graphic presentations.

- TECHNICAL MEMORANDUM. Scientific and technical findings that are preliminary or of specialized interest, e.g., quick release reports, working papers, and bibliographies that contain minimal annotation. Does not contain extensive analysis.

- CONTRACTOR REPORT. Scientific and technical findings by NASA-sponsored contractors and grantees.
- CONFERENCE PUBLICATION. Collected papers from scientific and technical conferences, symposia, seminars, or other meetings sponsored or cosponsored by NASA.

- SPECIAL PUBLICATION. Scientific, technical, or historical information from NASA programs, projects, and missions, often concerned with subjects having substantial public interest.

- TECHNICAL TRANSLATION. Englishlanguage translations of foreign scientific and technical material pertinent to NASA's mission.

Specialized services also include creating custom thesauri, building customized databases, organizing and publishing research results.

For more information about the NASA STI program, see the following:

- Access the NASA STI program home page at http://www.sti.nasa.gov

- E-mail your question via the Internet to help@sti.nasa.gov

- Fax your question to the NASA STI Help Desk at 301-621-0134

- Telephone the NASA STI Help Desk at 301-621-0390

- Write to:

NASA STI Help Desk

NASA Center for AeroSpace Information 7121 Standard Drive Hanover, MD 21076-1320 


\section{Measurement of Flow Pattern Within a Rotating Stall Cell in an Axial Compressor}

Jan Lepicovsky

QSS Group Inc., Cleveland, Ohio

Edward P. Braunscheidel

Glenn Research Center, Cleveland, Ohio

Prepared for

Turbo Expo 2006

sponsored by the American Society of Mechanical Engineers

Barcelona, Spain, May 8-11, 2006

National Aeronautics and

Space Administration

Glenn Research Center

Cleveland, Ohio 44135 


\section{Acknowledgments}

The work was sponsored by the NASA Glenn Research Center under the Intelligent Propulsion Systems Foundation Technologies by C.R. Mercer. The authors would like to thank J.P. Veres, chief of the GRC Compressor Branch, for his support and permission to publish the results of this study, and also G.E. Welch and K.L. Suder of NASA Glenn for their role in initiation of this work. Significant help from E.L. Parrott and R. Torres, both of NASA Glenn, is also gratefully acknowledged.

This work was sponsored by the Fundamental Aeronautics Program at the NASA Glenn Research Center.

Level of Review: This material has been technically reviewed by technical management.

Available from

NASA Center for Aerospace Information 7121 Standard Drive

Hanover, MD 21076-1320
National Technical Information Service 5285 Port Royal Road Springfield, VA 22161 


\title{
Measurement of Flow Pattern Within a Rotating Stall Cell in an Axial Compressor
}

\author{
Jan Lepicovsky \\ QSS Group, Inc. \\ Cleveland, Ohio 44135 \\ Edward P. Braunscheidel \\ National Aeronautics and Space Administration \\ Glenn Research Center \\ Cleveland, Ohio 44135
}

\begin{abstract}
Effective active control of rotating stall in axial compressors requires detailed understanding of flow instabilities associated with this compressor regime. Newly designed miniature high frequency response total and static pressure probes as well as commercial thermoanemometric probes are suitable tools for this task. However, during the rotating stall cycle the probes are subjected to flow direction changes that are far larger than the range of probe incidence acceptance, and therefore probe data without a proper correction would misrepresent unsteady variations of flow parameters. A methodology, based on ensemble averaging, is proposed to circumvent this problem. In this approach the ensemble averaged signals acquired for various probe setting angles are segmented, and only the sections for probe setting angles close to the actual flow angle are used for signal recombination. The methodology was verified by excellent agreement between velocity distributions obtained from pressure probe data, and data measured with thermoanemometric probes. Vector plots of unsteady flow behavior during the rotating stall regime indicate reversed flow within the rotating stall cell that spreads over to adjacent rotor blade channels. Results of this study confirmed that the NASA Low Speed Axial Compressor ( $L S A C$ ) while in a rotating stall regime at rotor design speed exhibits one stall cell that rotates at a speed equal to $50.6 \%$ of the rotor shaft speed.
\end{abstract}

\section{NOMENCLATURE}

$\begin{array}{lll}L_{T R} & {[\mathrm{~V}]} & \text { voltage trigger level, } \\ M a & {[1]} & \text { Mach number, } \\ n_{S H} & {\left[\mathrm{~min}^{-1}\right]} & \text { shaft rotative speed, } \\ p & {[\mathrm{kPa}]} & \text { pressure level, } \\ p_{S} & {[\mathrm{kPa}]} & \text { static pressure, } \\ p_{T} & {[\mathrm{kPa}]} & \text { total pressure, } \\ p_{W} & {[\mathrm{kPa}]} & \text { wall static pressure, } \\ t & {[\mathrm{~ms}]} & \text { time, } \\ V_{M} & {\left[\mathrm{m.s}^{-1}\right]} & \text { flow velocity, }\end{array}$

$\begin{array}{ll}\alpha_{F M} & {[d g]} \\ \varepsilon_{P} & {[d g]} \\ \eta_{D I R} & {[1]} \\ \xi_{D I R} & {[1]} \\ \rho V & {\left[\mathrm{~kg} \cdot \mathrm{m}^{-2} \cdot \mathrm{s}^{-1}\right]} \\ \tau_{S C P} & {[1]} \\ \psi_{P} & {[d g]} \\ I G V & \\ R B R & \\ \text { SVR } & \\ \text { UNC } & \end{array}$

flow angle, probe setting angle, direction coefficient (fiber probe), direction coefficient (pressure probe), throughflow density, nondimensional stall period, probe incidence, inlet guide vane, rotor blade row, stator vane row, uncorrected.

\section{INTRODUCTION}

Research efforts in axial compressors have recently focused on applications of active flow control of rotating stall aiming to increase the range of stable compressor operation (Refs. 1 through 3). In order to apply active control effectively, the flow instabilities during the rotating stall regime must be fully understood. Experimental research efforts to detect and analyze stall instabilities have been reported in Refs. 4 through 6. Most of the experimental data, available in the public domain, focuses on unsteady pressure measurements along the axis or circumference of a compressor shroud. Only a few references could be found dealing with measurement along a blade span during the rotating stall regime (Refs. 7 through 9).

Five types of high-response aerodynamic probes were used for this investigation. The first probe was a wall plug for wall static pressure measurement. Then, two types of standard thermoanemometric fiber probes were used to measure flow direction and throughflow density (a product of flow velocity and density) along the blade span. Finally, two newly designed, in-house built pressure probes with miniature transducers were used to measure the total pressure (pitot probe) and static pressure (disk probe) distributions along the blade height. 


\section{NASA LOW SPEED AXIAL COMPRESSOR}

The NASA Low Speed Axial Compressor (LSAC) is described in detail in Ref. 10. The research compressor consists of four identical axial stages. There is an inlet guide vane row in front of the first rotor. A compressor cross-section and the blade layout are shown in Fig. 1. The compressor is instrumented with multiple conventional aerodynamic probes, and there are several ports for unsteady probes. In this study, the focus is on two ports only. The first port $(\boldsymbol{S 0 5 A})$, is located in the IGV row close to the trailing edge at the mid pitch location. A wall plug measuring static wall pressure was inserted into this port for all the measurements reported here. The signal of this probe served as the synchronization signal, and as a base for conditional sampling for all the other probes employed during this investigation. The second port $(\boldsymbol{S 1 5 B})$ is located in the gap between the first stage rotor and stator. Thermoanemometric, and static and total pressure probes were inserted one by one in the flow through this port to measure the flow pattern in the rotating stall regime. The compressor was operated during this entire investigation at its design speed of $983 \mathrm{rpm}$, which corresponds to a blade tip speed of $61.0 \mathrm{~m} \cdot \mathrm{s}^{-1}$.

\section{HIGH RESPONSE AERODYNAMIC PROBES}

The wall static pressure probe was built in the form of a plug that could be easily mounted in any port in the compressor shroud. The pressure transducer used was a differential type of the lowest available pressure range, namely67 $\mathrm{kPa}(61 \mathrm{psid})$, with a natural frequency of the transducer diaphragm about $300 \mathrm{kHz}$. The pressure transducer is mounted in the plug with its diaphragm recessed $1 \mathrm{~mm}$ below the plug surface. Each wall plug has also a conventional static tap for steady state pressure measurements located next to the pressure transducer port. A view of a mounted wall plug from inside the compressor is presented in Fig. 2.

The thermoanemometric probes used were a split-fiber probe to measure flow direction and throughflow density, and

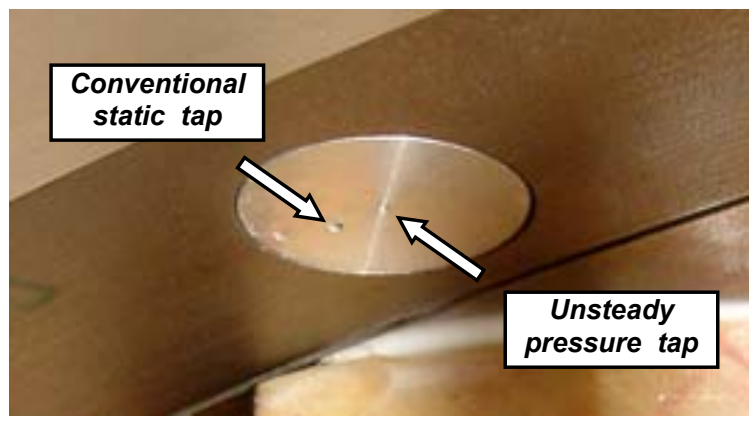

Fig. 2 Wall static pressure probe.

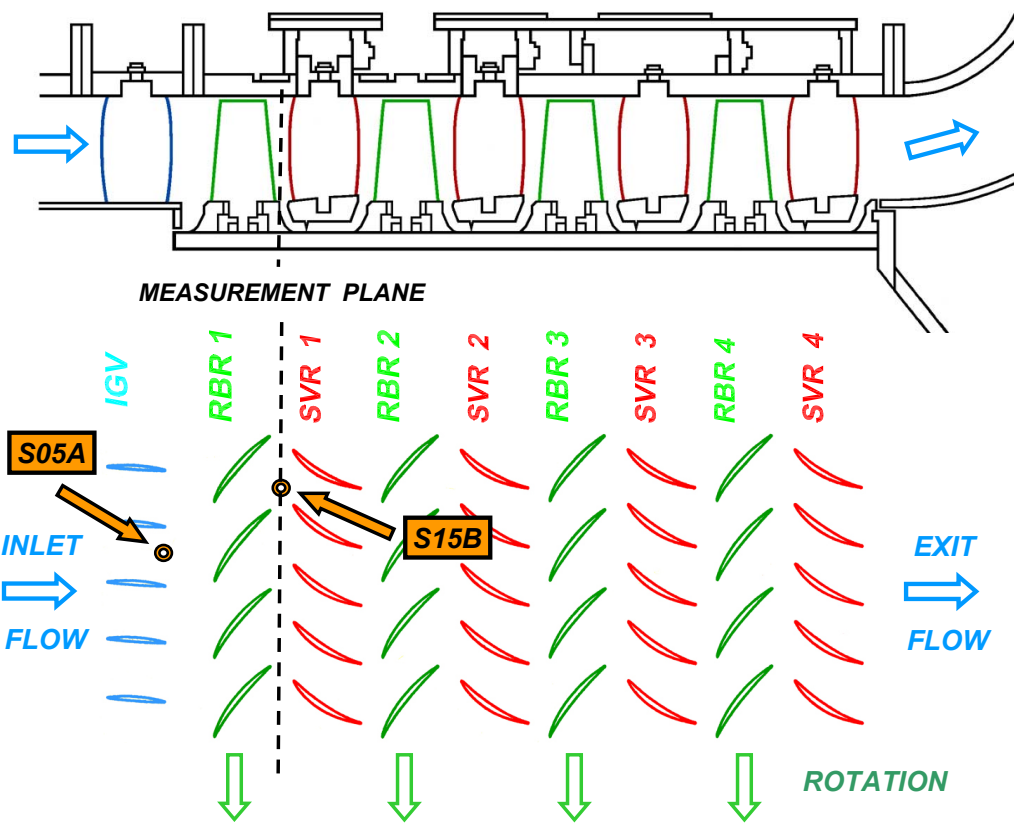

Fig. 1. Flow path and blading plan of the NASA low speed axial compressor with location of measurement stations.

a single-fiber probe to measure throughflow density only . A split-fiber probe positioned in the gap between the rotor and stator is shown in Fig. 3. A detailed description and experience gained with application of thermoanemometric fiber probes for measurement in $L A S C$ are given in Refs. 11 and 12, and therefore will not be repeated here.

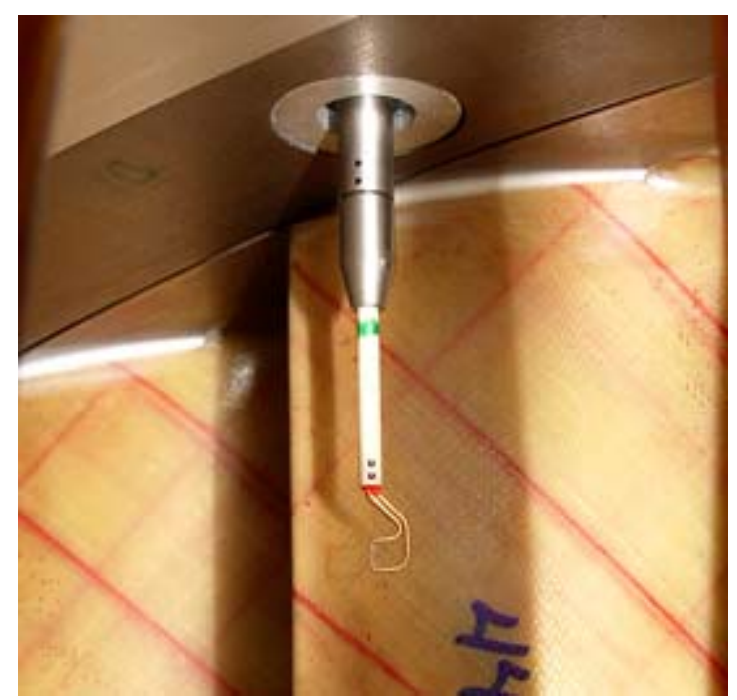

Fig. 3 Split-fiber probe in the gap between rotor and stator of the LSAC first stage.

The design of a total pressure probe is indicated in Fig. 4. A miniature pressure transducer is located in the probe head with its diaphragm oriented parallel to the axis of the receiving tube. The main advantage of this arrangement is: (1) perfect 


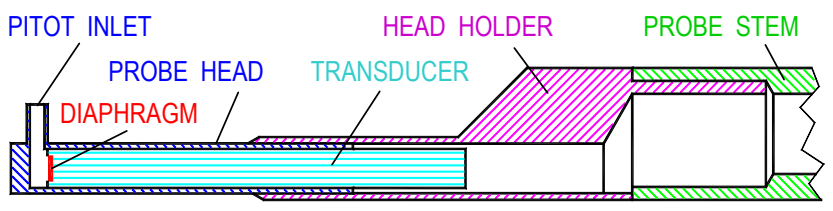

Fig. 4 Design of total pressure probe.

protection of the transducer diaphragm against dust particle damage, and (2) the smallest possible size of the probe head. On the other hand, this arrangement slightly decreases the frequency range of the probe in comparison to the case in which the transducer diaphragm is directly exposed to the oncoming flow. The natural frequency of the total pressure probe is $35 \mathrm{kHz}$, which was determined based on our experience with miniature pressure transducers mounted on oscillating blades (Ref. 13). An overall view of this probe mounted in the compressor behind the first rotor is in Fig. 5.

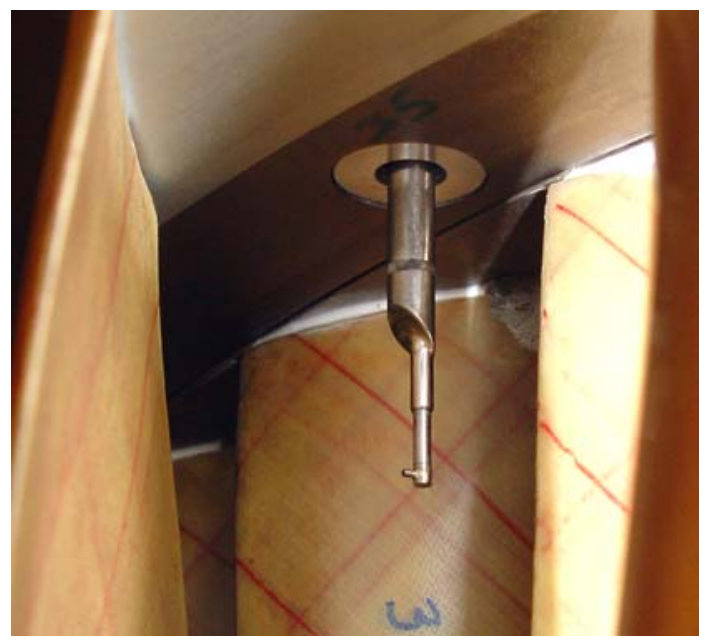

Fig. 5 View of total pressure probe.

The last probe to be used was a static pressure probe built for in-flow measurement. The probe was designed and built as a disk probe with the disk parallel to the axial-tangential plane of the compressor. The probe design is shown in Fig. 6. The pressure transducer is located in the probe head $1 \mathrm{~mm}$ below the disk plane. The probe frequency range is $70 \mathrm{kHz}$. The probe positioned behind the first stage rotor is shown in Fig. 7.

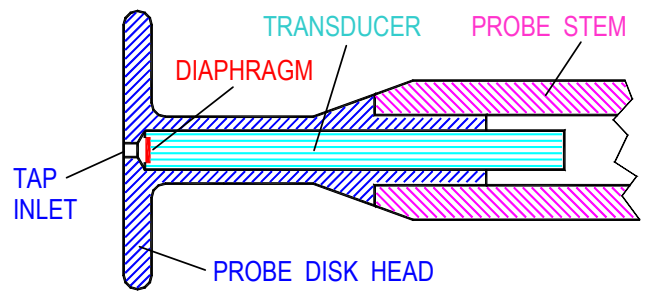

Fig. 6 Design of disk static pressure probe.

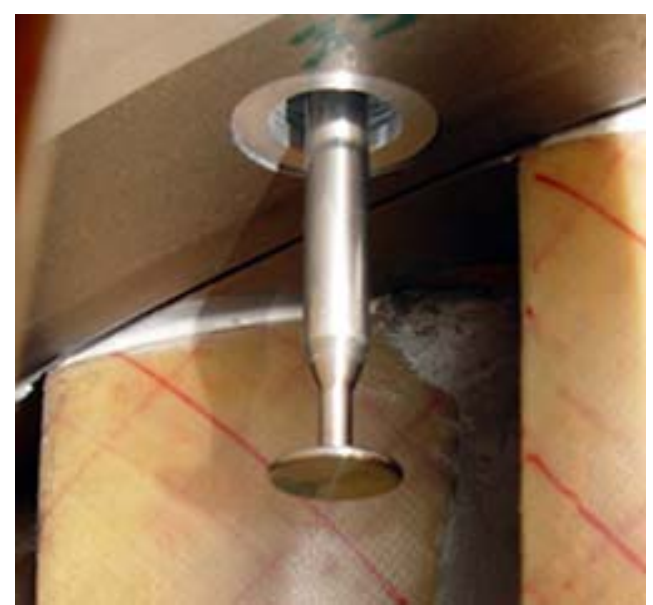

Fig. 7 View of disk static pressure probe.

\section{REGIME OF ROTATING STALL}

A rotating stall is an unstable operating regime that can be induced in a compressor by throttling the exit flow; subsequent opening of the exit throttle will bring the compressor back to stable operation. This event, as sensed by a wall static pressure probe located upstream of the $L S A C$ first rotor (Port $S 05 A$ in Fig. 1), is shown in Fig. 8. Three distinct phases of the rotating stall regime can be identified, as indicated in the picture. These phases are: stall inception, developed stall, and stall recovery. To measure the flow pattern, we have decided to focus on the stable phase of the rotating stall regime, to avoid transients in the flow field behavior. It appears, based on the pressure history presented, that the stability and periodicity of the developed stall phase of the rotating stall regime for the $L S A C$ is very high. This fact allowed the use of a procedure of conditional sampling based on the rotating stall zone passing frequency, which in turn allows synchronization of signals of various probes acquired for different test runs.

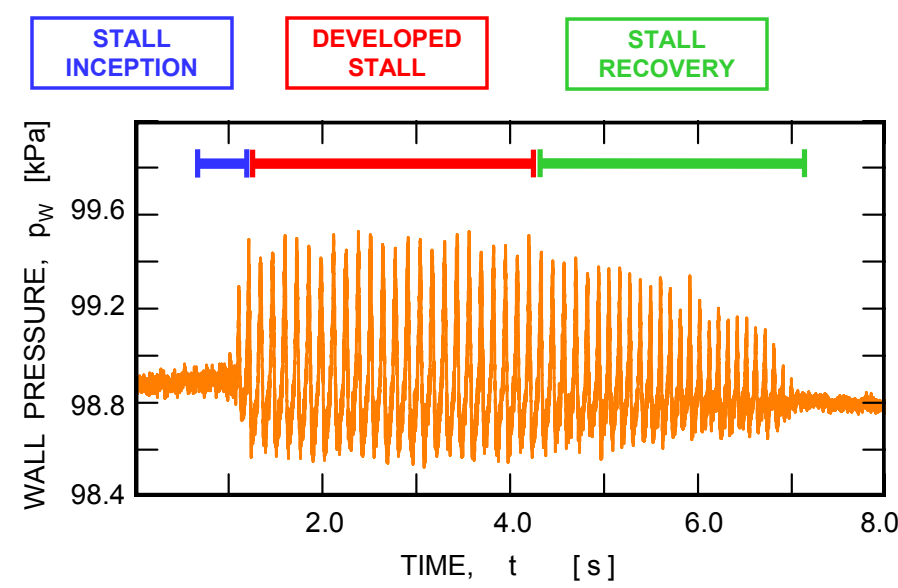

Fig. 8 Phases of rotating stall regime. 
To establish the ensemble averaging base signal, the wall static pressure signal was smoothed using a low pass filter and a running average; the smoothed out signal is shown in Fig. 9 with upper and lower thresholds, that generate intercepts with the pressure signal. The intercepts are shown in the scaled up segment in Fig. 10. The four intercepts, generated for each peak of the pressure signal were averaged to generate a time mark allocated to a given pressure peak (black triangle symbol). An array of time marks was then used to generate a base for ensemble averaging of signals from all the probes used in this study. The ensemble base signal is shown in Fig. 11.

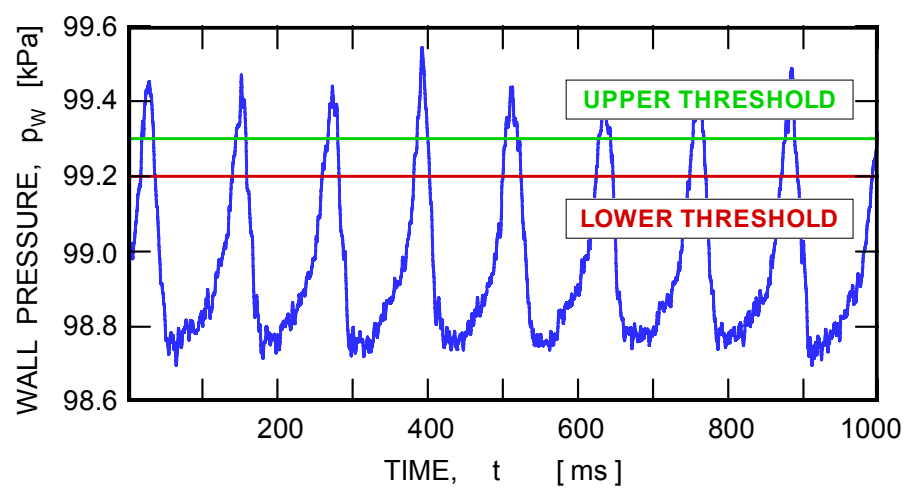

Fig. 9 Wall static pressure and intercept thresholds.

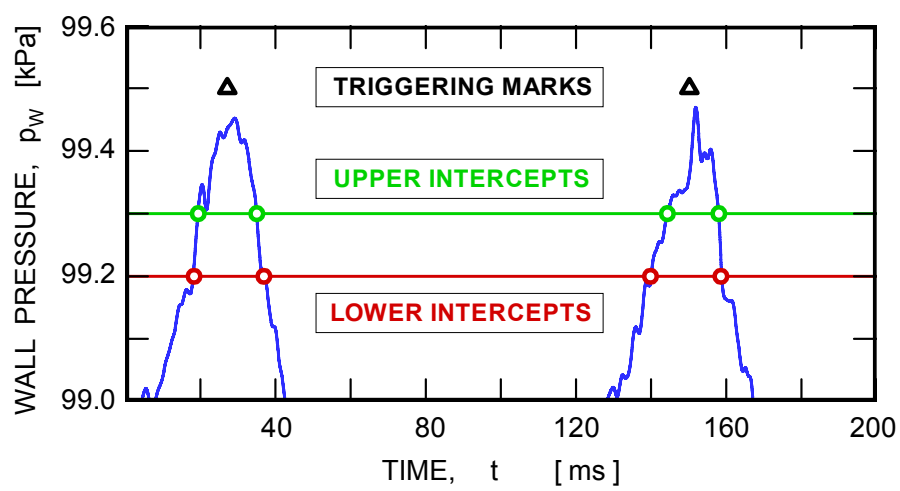

Fig. 10 Signal intercepts and triggering marks.

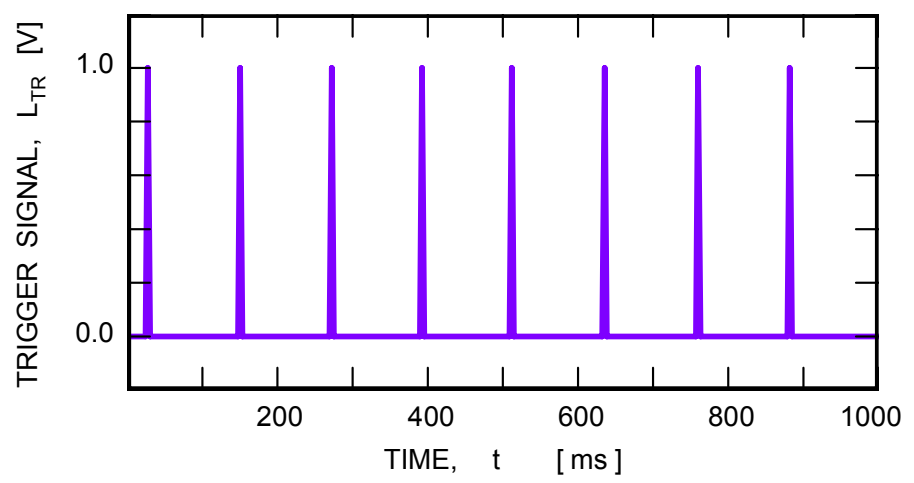

Fig. 11 Base signal for ensemble averaging.
The base signal represents the period (frequency) history of the stall cell rotation. Variation of the rotating stall period in time is plotted in Fig. 12. Inspection of data plotted in Figs. 8 and 12 , and the steadiness of the rotating stall period indicate that there is a single zone of rotating stall with an average period of $\tau_{R S}=120.7 \pm 4.6 \mathrm{~ms}$. It follows that the frequency of the rotating stall cell is $f_{R S}=8.29 \pm 0.22 \mathrm{~Hz}$. The rotor shaft frequency was $f_{S H}=16.39 \mathrm{~Hz}\left(n_{S H}=983.0 \mathrm{~min}^{-1}\right)$. The ratio of rotating stall and shaft frequencies is $\varphi_{S S}=0.506$.

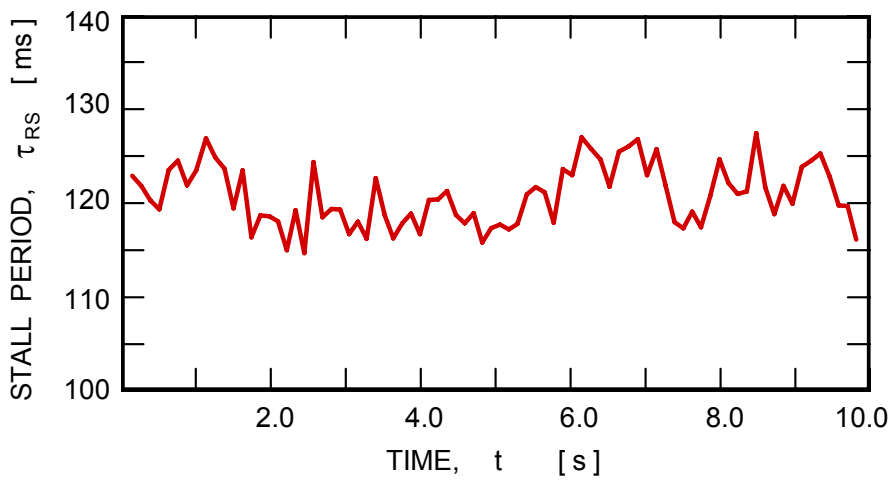

Fig. 12 Variation of rotating stall period.

\section{THERMOANEMOMETRIC DATA}

Signals acquired by a split-fiber probe can be decomposed into a flow angle in the axial-tangential plane and throughflow density data. The decomposition procedure for a split-fiber probe is described in details in Refs. 11 and 12 and will not be repeated here.

Flow angle distributions for two probe setting angles are shown in Fig. 13. The distributions were generated by applying the ensemble averaging procedure to the flow angle data. To improve the readability of the data each diagram depicts the same distribution plotted twice next to each other. As seen in Fig. 13, the signals differ significantly from each other for different probe setting angle. A summary plot shown in Fig. 14 was generated to observe the signal behavior as a function of the wide range of probe setting angles. The data collapse is quite good for the unstalled portion of the rotor flow as long as the probe incidence is less than $640 \mathrm{dg}$; the probe incidence is the difference between the probe setting angle and the instantaneous flow angle. For incidence less than $\pm 40 d g$ the directional characteristic of a split-fiber probe is linear (Ref. 13). The traces for probe setting angles larger than $89 d g$ are outside of the probe linear range and consequently do not collapse with data for smaller setting angles. Signals within the stall cell, however, are very dependent on the probe setting angle. The detected flow angles at some points $\left(\tau_{S C P}=0.90\right)$ exhibit extreme range of values from $20 \mathrm{dg}$ through $140 \mathrm{dg}$. Obviously this wide range of detected flow angles for different probe setting angles is a probe effect that must be accounted for by a data reduction procedure. 


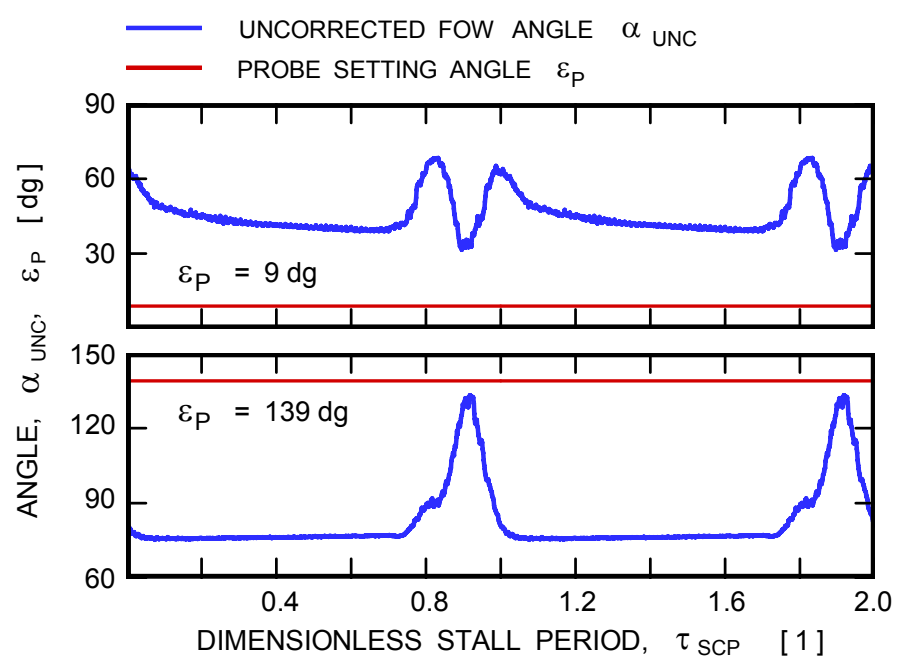

Fig. 13 Detected flow angle distributions for two setting angles of a split-fiber probe.

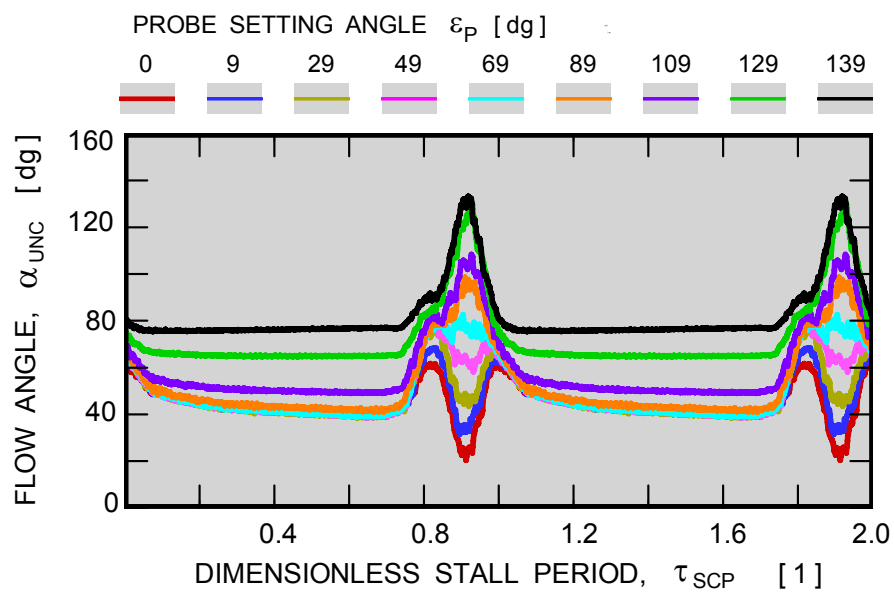

Fig. 14 Detected flow angles as function of split-fiber probe setting angle.

A split-fiber probe and a cross-section of the sensor cylinder are shown in Fig. 15. Signals generated by this probe are proportional to the heat transfer flux from two halves of the sensor cylinder $S 1$ and $S 2$ (Refs. 11 and 12). The probe has two planes of symmetry, one along the plane that separates two semi-cylindrical sensors (probe incidence $0 d g$ ), and the other one that is perpendicular to this plane (probe incidence $90 \mathrm{dg}$ ). Increasing the flow angle in the axial-tangential plane increases the heat flux difference between two probe sensors linearly up to an incidence of $40 \mathrm{dg}$. Beyond that angle the probe is progressively less sensitive to flow direction. The heat flux difference still increases, with further increasing incidence, although nonlinearly, and only up to an incidence of $90 \mathrm{dg}$. If the flow incidence increases even further beyond the second plane of symmetry, the flux difference starts to decrease, which is interpreted by the decomposition procedure as a decreasing flow angle. This is precisely what happens in the rotating stall zone where the flow angle deviates significantly from the flow angle in the unstalled portion of the rotor flow. In order to

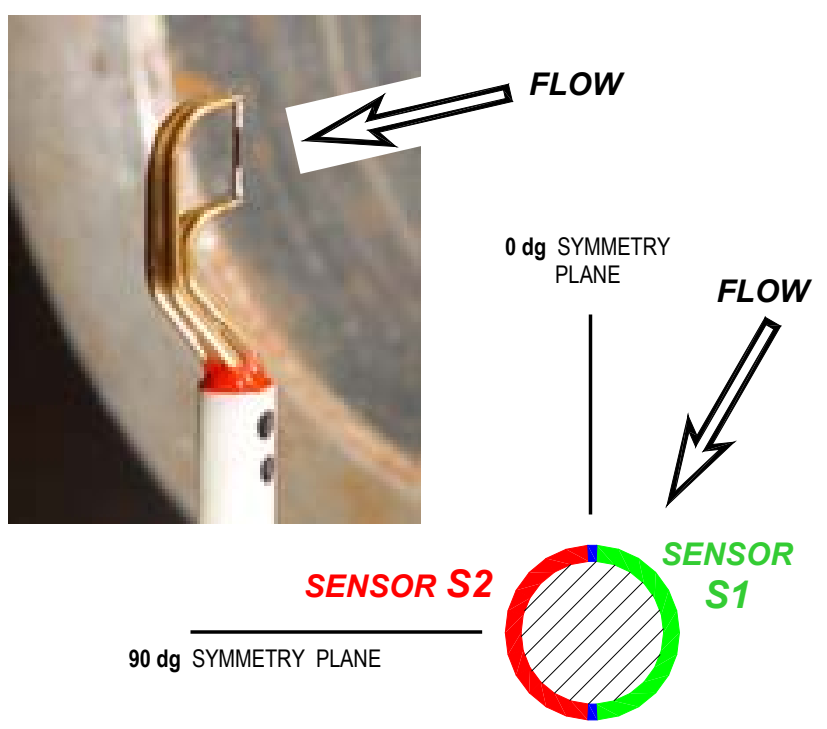

Fig. 15 Geometry of a split-fiber probe.

measure the flow angle correctly, the probe should follow the flow angle changes so the deviation between the instantaneous flow angle and the probe setting angle (probe incidence) would always be less than $40 \mathrm{dg}$. This is very impractical and would be very costly. Fortunately, the flow pattern during the developed stall phase is very stable with excellent periodicity, which enables segmentation of the ensemble average data into intervals such that the probe incidence is always less than $40 \mathrm{dg}$. Then, the flow angle detected within each segment is the true flow angle free of the probe nonlinearity and ambiguity contamination effects. The resulting flow angle distribution for the entire ensemble averaged interval is then acquired by patching partial signals from individual segments together. The necessary condition for this partial signal addition is the excellent periodicity of the flow phenomenon investigated. The resulting flow angle data and the corresponding probe setting angle are shown in Fig. 16. As seen in this diagram, the flow angle is practically constant (about $45 \mathrm{dg}$ ) in the unstalled portion of the rotor flow, then rapidly increases up to $130 \mathrm{dg}$ in

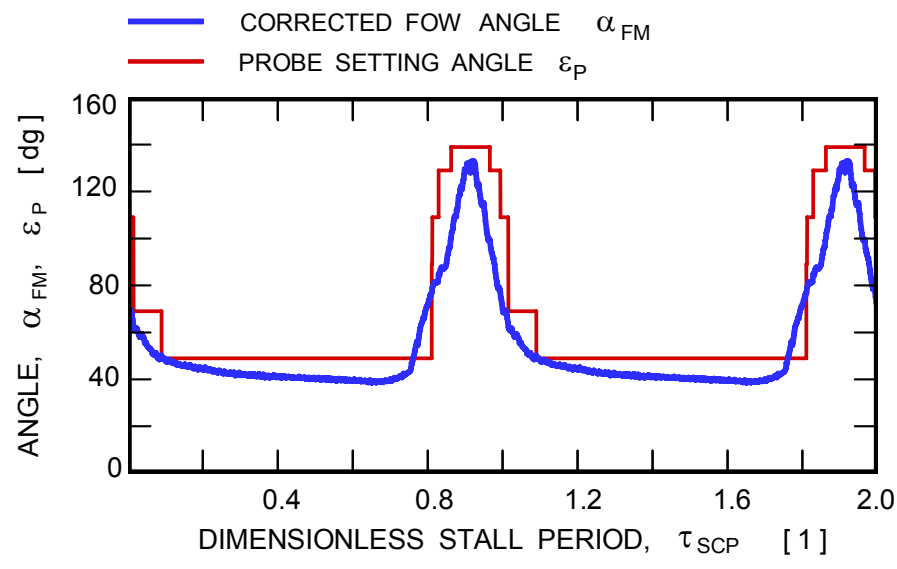

Fig. 16 Absolute flow angle distribution. 
the stall cell, and after that decreases again to the unstalled level. The fact that the flow angle rises beyond $90 \mathrm{dg}$ (which is the direction of the rotor blade motion) indicates a short presence of reversed flow in the rotating stall cell. The validity of this procedure of flow angle determination could not be verified directly, because at present there is no independent method of instantaneous flow angle measurement available. However, we believe that the method presented was verified indirectly by unsteady pressure probes as discussed later.

The other signal that can be derived from a split-fiber data set is the throughflow density, which for incompressible flow with constant flow temperature is directly proportional to the flow velocity. A summary plot showing the effects of the probe setting angle on the detected throughflow density levels is shown in Fig. 17. In order to remove the probe effects from the acquired data the same approach was used as for the flow angle data. The throughflow density signals were segmented using the same intervals as before, and the resulting signal was created by addition of individual segments free of the probe setting angle effects. The resulting throughflow density signal is in Fig. 18. As seen here, the throughflow density increases very mildly within the unstalled portion of the flow. There is

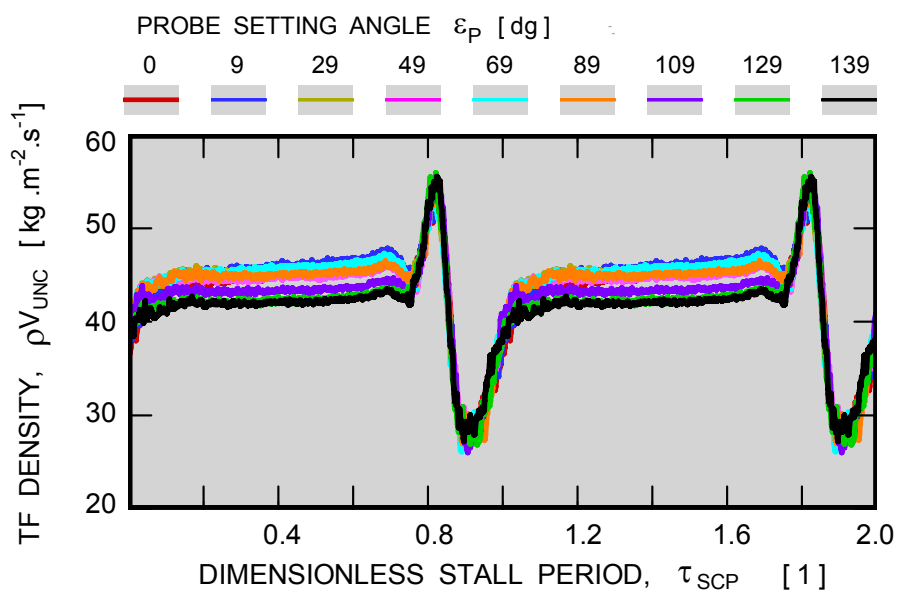

Fig. 17 Detected throughflow density distributions as function of split-fiber probe setting angle.

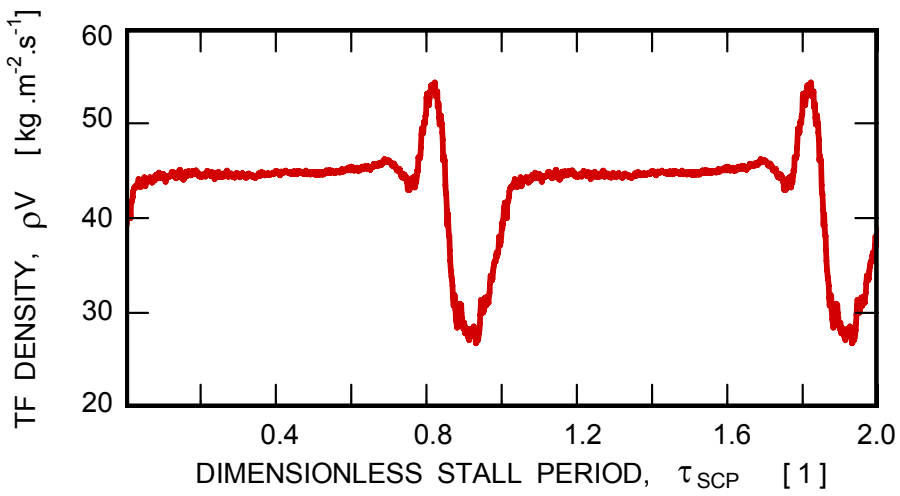

Fig. 18 Corrected throughflow density distribution measured by split-fiber probe. a very short interval for which the throughflow density decreases a little just at the arrival of the rotating stall cell, followed by a rapid increase and then rapid decrease as the rotating stall cell passes the probe. As the flow starts to recover from the stall, the throughflow density rises again back to the attached flow level.

The distribution of the throughflow density can be independently verified by using a single element thermoanemometric fiber probe. A single-fiber probe with a sensor perpendicular to the axial-tangential plane is in theory insensitive to flow direction in this plane, and thus measures directly the magnitude of the throughflow density vector. In practice, in particular for very large angle changes, there is a detectable effect that the probe prongs have on the overall heat transfer from the probe sensor. A summary plot of a singleelement fiber probe data is shown in Fig. 19. As seen here, the throughflow density distribution, although similar in shape to one obtained from the split-fiber probe, still exhibits visible dependence on the probe setting angle. The probe was recalibrated for huge incidence variations (from $0 d g$ up to $160 \mathrm{dg}$ ) in a steady free jet flow emanating from a $38 \mathrm{~mm}$ calibration nozzle. The resulting directional coefficient that

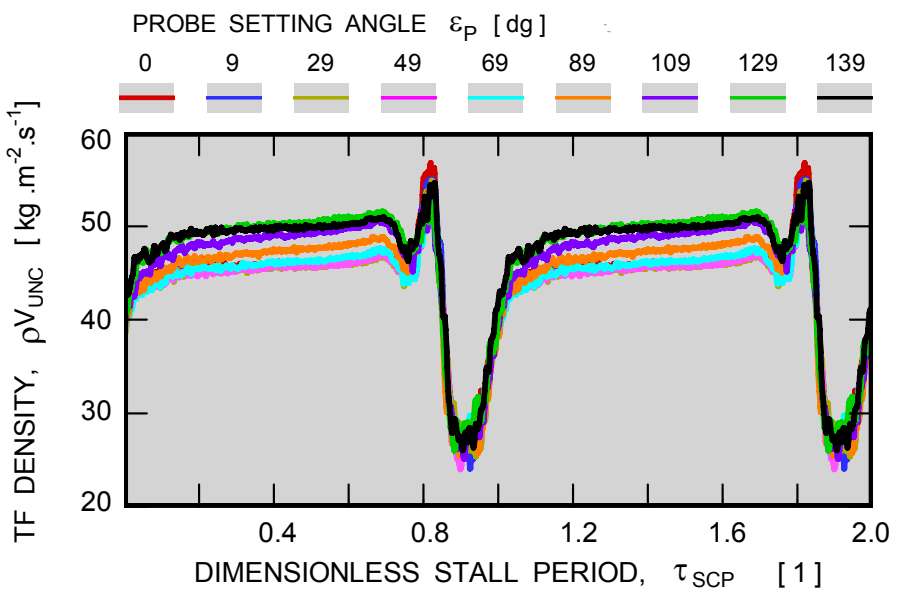

Fig. 19 Detected throughflow density distributions as function of single-fiber probe setting angle.

corrects the measured signal by eliminating contamination caused by probe prongs is shown in Fig. 20. This directional coefficient was used to correct data plotted in Fig. 19. To perform the correction, an instantaneous probe incidence was determined from the particular probe setting angle and the instantaneous flow angle distribution presented in Fig. 16. The corrected single-fiber probe data collapsed together as the effects of probe setting angle were eliminated (Fig. 21). The corrected single-fiber probe data were averaged for all probe setting angles used, and are shown in Fig. 22 together with a throughflow density distribution measured by a split-fiber probe. As seen in this figure, the overall agreement between data from both probes is very good, particularly outside the stall zone. However, inside the rotating stall zone, there is a 
visible overshoot of split-fiber probe data. The reason for this $10 \%$ overshoot is not clear at present, but it may be a consequence of the higher frequency range of the split-fiber probe than that of the single-fiber probe (Ref. 12). An average of these two distributions was used as the reported distribution of the throughflow density in the rotor flow.

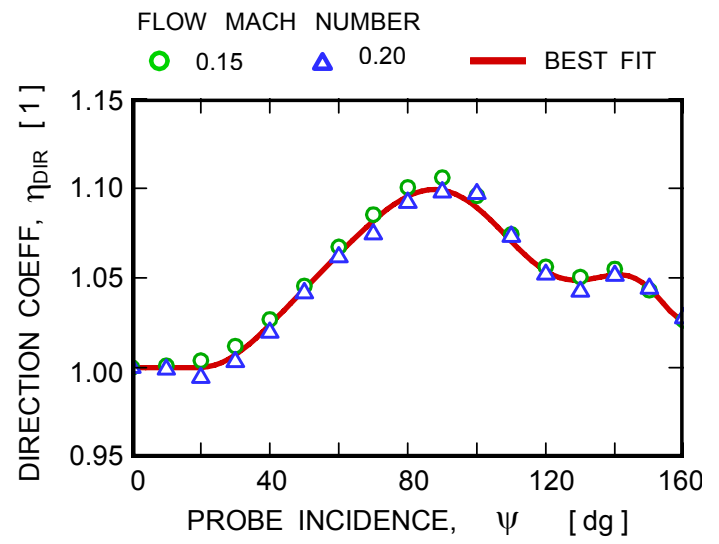

Fig. 20 Direction coefficient of single-fiber probe as function of probe incidence.

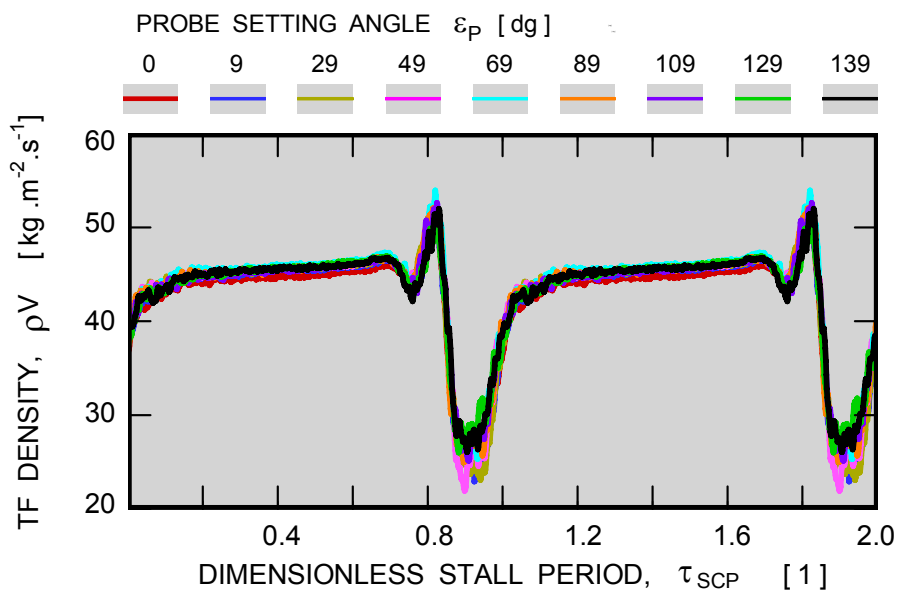

Fig. 21 Corrected throughflow density distributions measured by single-fiber probe.

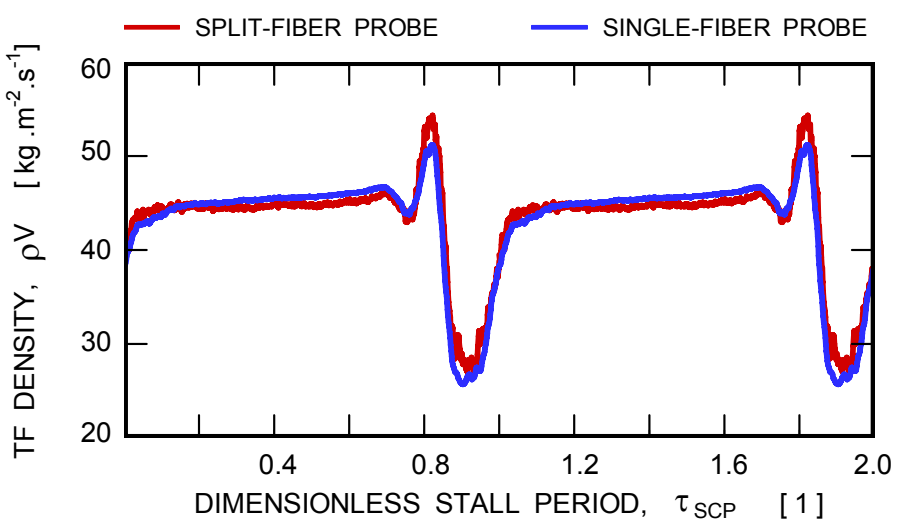

Fig. 22 Comparison of throughflow density distributions measured by split- and single-fiber probes.

\section{FLOW PRESSURE DATA}

The flow static pressure data was measured at blade midspan at the same port $(S 15 B)$ at which the thermoanemometric data was taken. The static pressure probe was expected to be insensitive to flow direction in the axialtangential plane. A summary plot in Fig. 23 shows ensemble averaged data for all seven setting angles of the static pressure probe. As seen in this picture, the rotating stall cell occupies an interval of $\tau_{S C P}$ from 0.75 through 1.05 . The static pressure rises slowly in the unstalled portion of the rotor flow (from $\tau_{S C P}$ equal to 0.05 through 0.75 ), and then suddenly drops and sharply rises again $\left(\tau_{S C P}=0.8\right)$ to a level that is higher than the pressure level in the unstalled portion of the flow. Static pressure then stays about constant for the remaining portion of the stall cell and lowers again as the flow attaches back to the rotor blades $\left(\tau_{S C P}=1.05\right)$. It should be noted here, that the ensemble averaging procedure is based on the passing frequency of the rotating stall cell, which is not an integer multiple of the blade passing frequency. Consequently, any unsteadiness associated with the blade passing frequency is averaged out during the ensemble averaging procedure, and is not visible in the pressure traces. As seen in Fig. 23, the data collapse is excellent, with only a small scatter in the stall cell. The results confirm the expected directional insensitivity of the static pressure probe, and the data in Fig. 23 represents the true static pressure distribution during the developed stall regime.

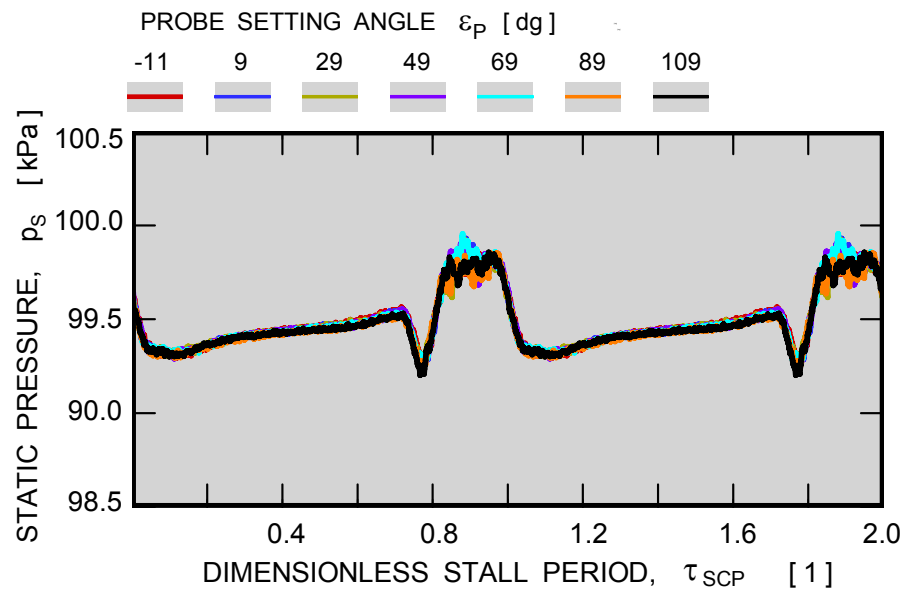

Fig. 23 Detected static pressure distributions as function of static pressure probe setting angle.

The last signal to be reduced was flow total pressure measured at the blade midspan. The total pressure probe is quite sensitive to changes in flow direction, as witnessed in Fig. 24 where data for two setting angles of the total pressure probe are shown. The differences are huge; data for all probe setting angles used are shown in a summary plot in Fig. 25. These differences are due to the relatively narrow directional characteristics of the total pressure probe depicted in Fig. 26. It appears that for flow Mach numbers above 0.1 the directional characteristics practically do not change, simplifying the correction procedure. The uncorrected total 
data were segmented in the same way as previously described for the correction of flow angles. Then, within each segment, the total pressures were corrected for incidence angle effects.

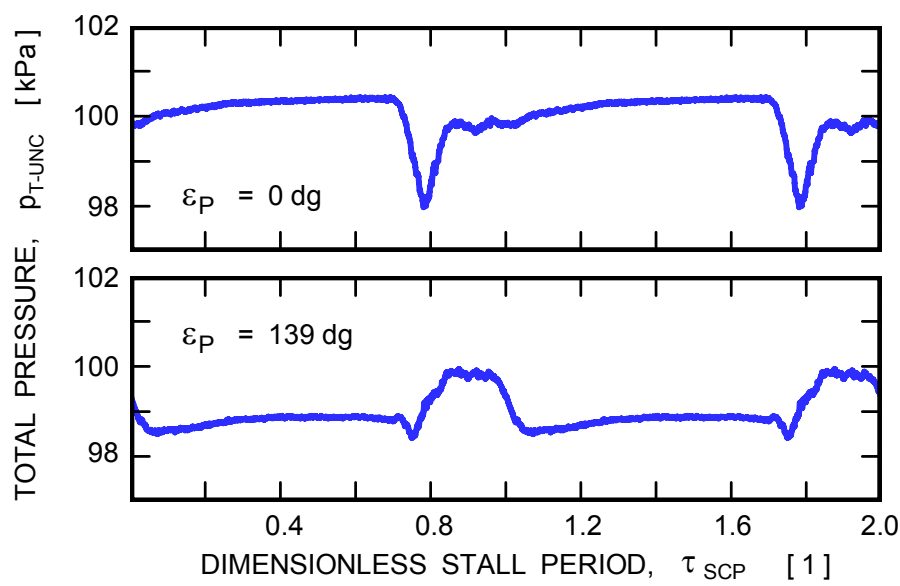

Fig. 24 Detected total pressure distributions for two setting angles of a total pressure probe.

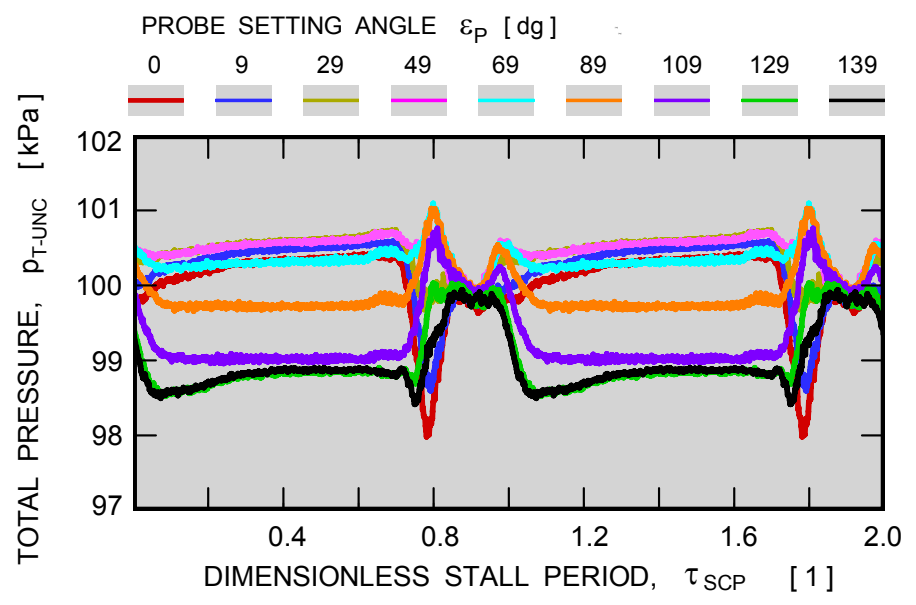

Fig. 25 Detected total pressure distributions as function of totat pressure probe setting angle.

FLOW MACH NUMBER

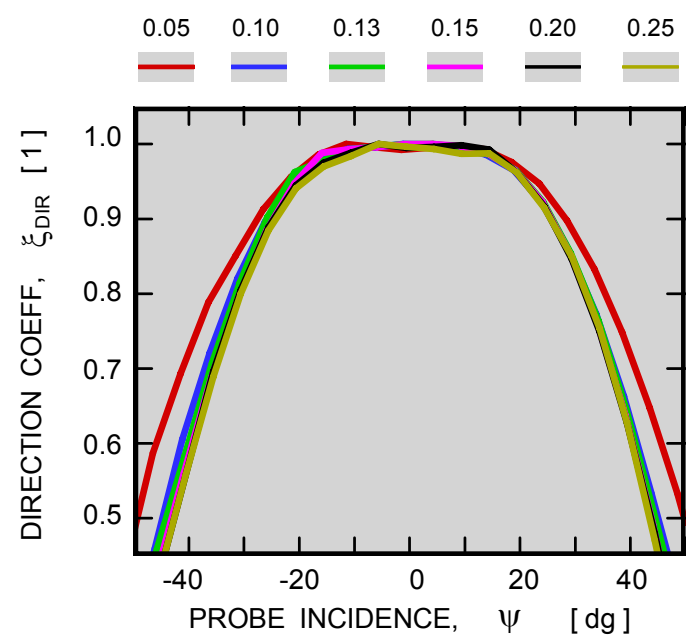

Fig. 26 Direction coefficient of total pressure probe.
The directional characteristics, shown in Fig. 26, were derived for the dynamic pressure portion of the total pressure. Thus, before applying the directional corrections on the data depicted in Fig. 25, the instantaneous dynamic pressure must be determined by subtracting the instantaneous values of static pressure that was averaged for all probe setting angles and is shown in Fig. 27. After the total pressure values were corrected in each segment, the total pressure distribution for the entire period of the rotating stall cell revolution was created by adding individual segments together. The corrected total pressure distribution is shown in Fig. 27.

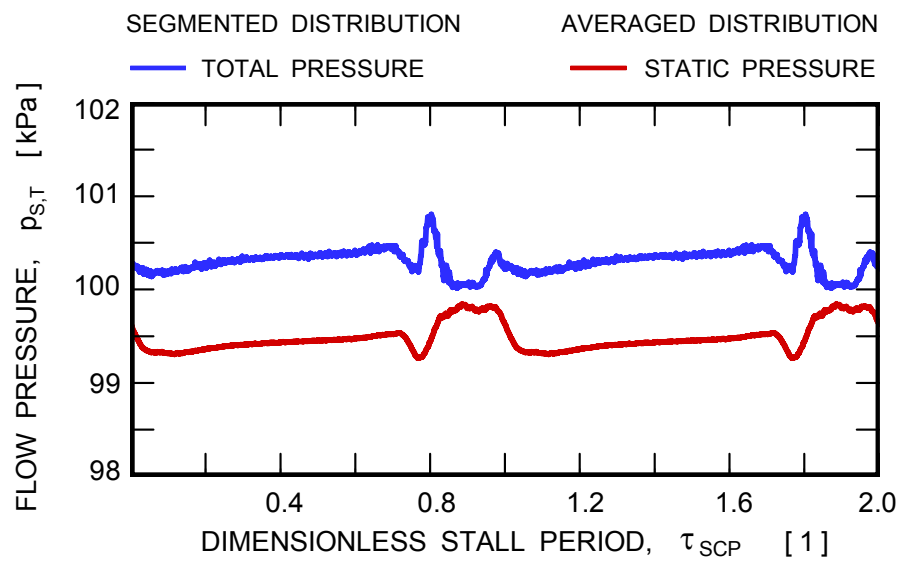

Fig. 27 Distributions of flow pressures in rotor exit flow during developed stall regime.

\section{FLOW PATTERN IN THE ROTATING STALL CELL}

Having determined all the flow parameters, the flow pattern within the rotating stall cell can now be reconstructed. The distribution of Mach number magnitude shown in Fig. 28 was obtained utilizing the total and static pressure distributions presented in Fig. 27. The magnitude of flow velocity can be determined from the Mach number distribution provided that instantaneous values of flow static temperature are known. Distribution of static flow temperature, however, is not available; the only temperature measurements that were made were of the total temperature at the entrance in the compressor inlet nozzle. The research compressor is a low speed, low pressure axial machine with an average total temperature rise over the first stage of less than $1.5 \mathrm{~K}$. Therefore, a decision was made to calculate flow velocity based on measured Mach number distribution and constant total temperature equal to the inlet total temperature plus $1 \mathrm{~K}$. The resulting distribution of velocity magnitude is shown in Fig. 29 (pressure probe data).

The velocity magnitude distribution based on data acquired by pressure probes can be verified by comparing it with the velocity levels based on data obtained from thermoanemometric probes. Distributions of throughflow density, shown in Fig. 22, can be converted to velocity plots 


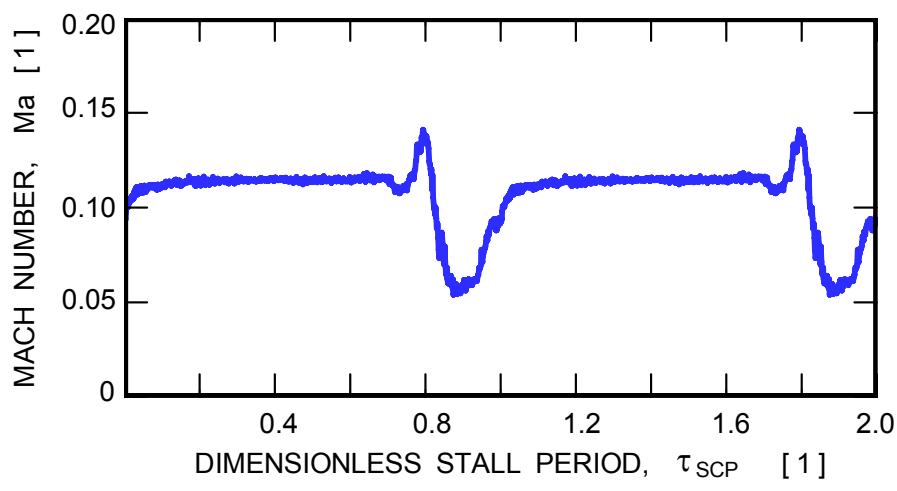

Fig. 28 Mach number distribution determined from pressure probe measurements.

knowing the distribution of flow density. The flow density distribution was determined using the static pressures shown in Fig. 27, and the measured inlet total temperature with the same assumption discussed above. The computed thermoanemometric probe based velocity distributions are plotted in Fig. 29 to be compared with the pressure probe based velocity distribution. The results presented agree extremely well. This agreement is proof of the soundness of the approach adopted for correction of acquired data by segmenting signals into intervals for which the probes operate within a relatively narrow angle of acceptance. Of course, as stated earlier, a necessary condition for this approach is the periodicity of the signal under investigation.

Finally the flowfield in a rotating stall cell at the exit from the first stage rotor can be constructed. The flowfield pattern is shown in Fig. 30 in a form of vector plots. It should be realized that the picture depicts time resolved measurements obtained at a fixed point. The spatial separation of individual velocity vectors represents the sequence of velocity vector changes in time at a given fixed point. The spatial separation of velocity vectors was scaled to match the rotor solidity. The scaling was based on the average time of one revolution of the rotating stall cell $(123.03 \mathrm{~ms})$, the average time of one rotor revolution $(61.04 \mathrm{~ms})$, and the number of rotor blades (39). The picture depicts development of the two-dimensional velocity vector, as well as the development of the axial velocity component. The "line of measurement" (fixed spatial point resolved in a line in the time domain), is indicated by a broken line past the rotor row.

It is obvious from the presented flow pattern that there is a relatively strong reversed flow region in the core of the rotating stall cell. This reversed flow

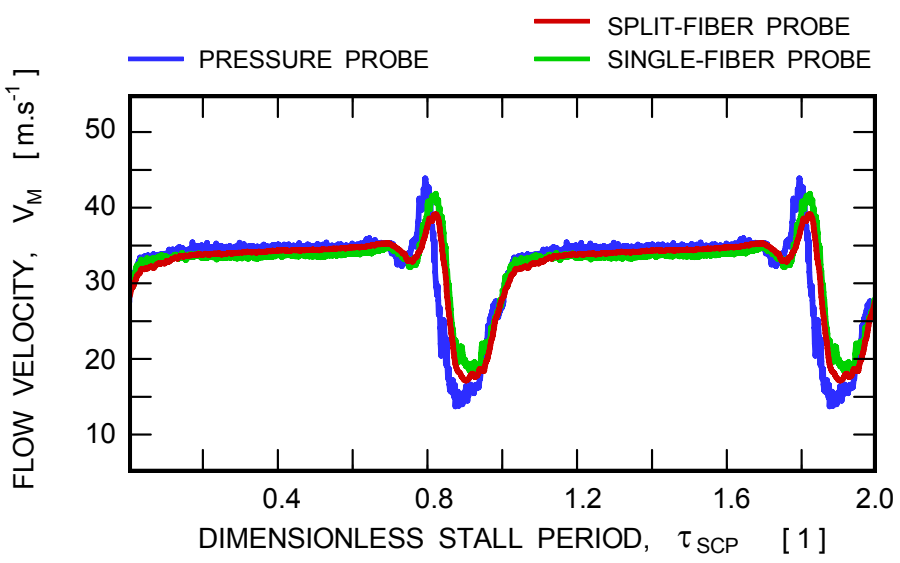

Fig. 29 Comparison of velocity magnitude distributions determined from thermoanemometric and pressure probe data.

region spreads over two adjacent rotor blade channels. The presence of the rotating stall cell affects the flow pattern in at least six rotor blade channels, which for the compressor investigated is about $15 \%$ of the rotor circumference.

\section{UNCERTAINTIES AND ERROR ANALYSIS}

The level of confidence in the achieved results can be corroborated by an error analysis. Two types of uncertainties were encountered during this research. First, there are errors or uncertainties associated with the accuracy of probe positioning and the sensitivity of transducers. These errors are negligible.

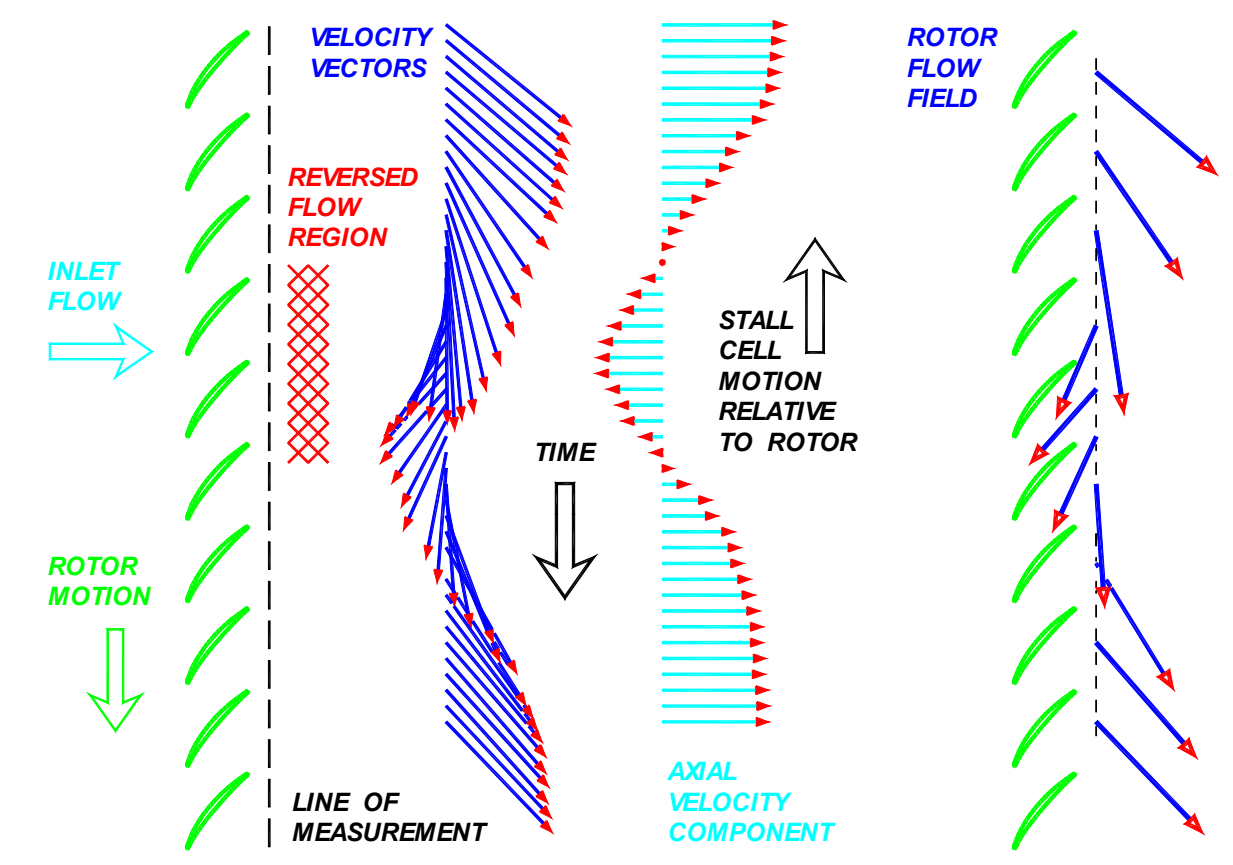

Fig. 30 Flow pattern in a rotating stall cell. 
The probe actuators move the probes with an accuracy better than $\pm 0.1 \mathrm{~mm}$ and $\pm 0.05 \mathrm{dg}$. The compressor rotative speed was measured with accuracy of $\pm 0.01 \%$. Pressure transducers, built in the pressure probes, have a full scale range of $\pm 7.0 \mathrm{kPa}( \pm 1.0 \mathrm{psid})$. A multipoint calibration procedure was used for pressure transducers and calibration data were fitted with a second order polynomial to account for calibration nonlinearity. The zero drift was measured before and after each test run, and accounted for. The accuracy of thermoanemometric probe calibration deteriorates at very low flow velocities. However, for the present investigation, the value of throughflow density was always above $20 \mathrm{~kg} \cdot \mathrm{m}^{-2} \cdot \mathrm{s}^{-1}$, and at those levels the standard deviation of calibration and fitted data is less than $1.0 \mathrm{~kg} \cdot \mathrm{m}^{-2} \cdot \mathrm{s}^{-1}$ (Ref. 11).

All unsteady data were conditioned, and recorded in digital form using 12-bit digitizers. The data were recorded with a sampling frequency of $32 \mathrm{kHz}$ in segments $10 \mathrm{~s}$ long. The maximum digitizing error was less than $\pm 10 \mathrm{~Pa}$ for pressure data, and less than $\pm 0.04 \mathrm{~kg} \cdot \mathrm{m}^{-2} \cdot \mathrm{s}^{-1}$ for thermoanemometric data. On the basis of measured unsteady pressure and velocity magnitudes, these errors are about $\pm 1.0 \%$ for pressure measurements, and about $\pm 0.1 \%$ for throughflow density measurements.

Noticeably larger uncertainties are associated with the randomness of flow parameters in the rotor flow, particularly in separated flow regions. As indicated in Fig. 12, the measured rotating cell frequency was $f_{R S}=8.29 \pm 0.22 \mathrm{~Hz}$, which represents $2.7 \%$ fluctuations. These frequency fluctuations were corrected for during ensemble averaging by data resampling to an average rotating stall period. Each ensemble average was generated from 82 rotating stall periods.

The distributions of pressure and velocity random unsteadiness are shown in Figs. 31 and 32. The pressure standard deviation level outside of the rotating stall region is very low, about $60 \mathrm{~Pa}$ (digitizing error is $10 \mathrm{~Pa}$ ). In the separated flow region the standard deviation suddenly jumps up close to $500 \mathrm{~Pa}$. Standard deviations of measured throughflow density are even larger as depicted in Fig. 32.

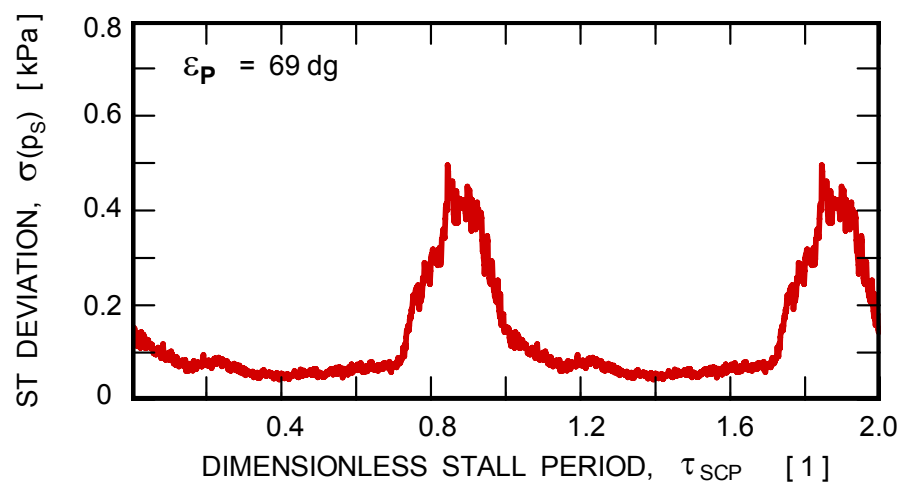

Fig. 31 Standard deviations of ensemble average measured by static pressure probe.

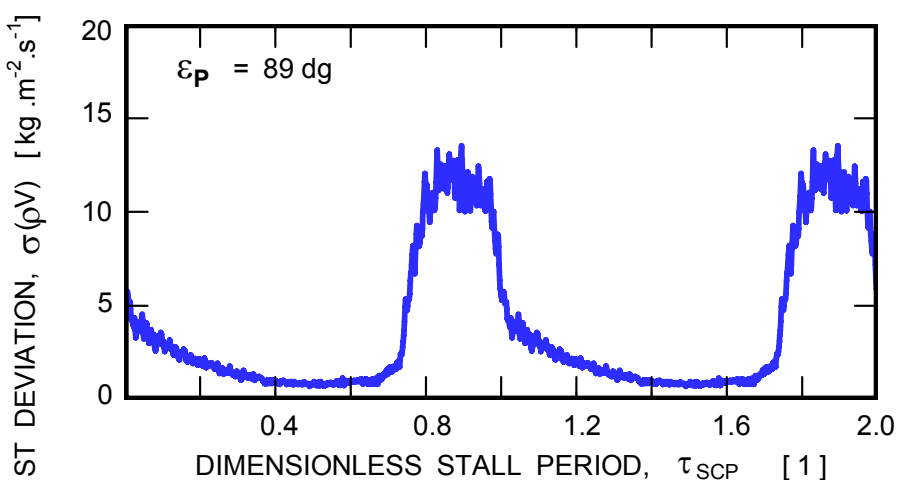

Fig. 32 Standard deviations of ensemble average measured by single-fiber probe.

Outside the rotating stall region the standard deviations are very low, however inside the stall region the amplitude of deviations increases by a factor of twelve. It is obvious, that the ensemble average must be generated from a large number of stall periods, 82 in our case, for results to have statistical significance.

\section{CONCLUSIONS}

The following results were obtained during the course of this study:

- Miniature total and static pressure probes with fast response pressure transducers were built, calibrated and used in a research compressor for investigation of rotating stall.

- A methodology was developed to reduce data from pressure and thermoanemometric probes operating in unsteady flows with huge changes of flow direction that are significantly larger than the acceptance range of probe incidence.

- Unsteady flow parameters inside a rotating stall cell were determined using ensemble averaging based on rotating stall frequency.

- Excellent agreement between velocity distributions obtained from pressure probe data with data determined by thermoanemometric probes mutually verifies their performance, and also confirms the validity of the derived data reduction methodology.

- Vector plots of unsteady behavior during the rotating stall regime indicate reverse flow within the rotating stall cell that spreads over to adjacent rotor blade channels.

- The NASA Low Speed Axial Compressor while in the rotating stall regime at the design rotor speed exhibits one stall cell that rotates with a speed equal to $50.6 \%$ of the rotor speed. 


\section{REFERENCES}

1. Paduano, J.D., Epstein, A.H., Valavani, L., Longley, J.P., and Greitzer, E.M.: "Active Control of Rotating Stall in a Low speed Axial Compressor", ASME Journal of Turbomachinery, Vol. 115, pp. 48-56, 1993.

2. Weigl, H.J., Paduano, J.D., Frechette, L.G., Epstein, A.H., Greitzer, E.M., Bright, M.M., and Strazisar, A.J.: "Active Stabilization of Rotating Strall and Surge in a Transonic Single Stage Axial Compressor", Paper ASME-GT-411, 1997.

3. Freemen, C., Wilson, A.G., Day, L.J., and Swinbanks, M.A.: "Experiments in Active Control of Stall on an Aeroengine Gas Turbine", Paper ASME 97-GT-316, 1997.

4. McDougall, N.M., Cumpsty, N.A., and Hynes, T.P.: "Stall Inception in Axial Compressors", ASME Journal of Turbomachinery, Vol. 112, pp. 116-125, 1990.

5. Tryfonidis, M., Etchevers, O., Paduano, J.D., Epstein, A.H., and Hendricks, G.J.: "Pre-Stall Behavior of Several High-Speed Compressors", ASME Journal of Turbomachinery, Vol. 117, pp. 62-80, 1995.

6. Methling, F.O., Stoff, H., and Grauer, F.: "The Pre-Stall Behavior of a 4-Stage Transonic Compressor and Stall Monitoring Based on Artificial Neural Networks", International Journal of Rotating Machinery, Vol. 10, pp. 387-399, 2004.

7. Dunham, J.: "A probe for measuring fluctuating flows in axial compressors", Journal of Scientific Instruments, Vol. 39, pp. 328-355, 1962.
8. Gossweiler, C., Kupferschmied, P., Humm, H.J., Gyarmathy, G.: "On Fast-Response Probes, Parts 1 \& 2", ASME Journal of Turbomachinery, 1995.

9. Nie, C., Chen, J., Jiang, H, and Xu, L.: "Experimental analysis on the unsteady behavior of modal stall inception in a low-speed axial compressor", Paper ISABE 99-7218, 1999.

10. Wasserbauer, C.A., Weaver, H.F., and Senyitko, R.G.: "NASA Low-Speed Axial Compressor for Fundamental Research", NASA TM-4653, 1995.

11. Lepicovsky, Jan.: "Application of a Split-Fiber Probe to Velocity Measurement in the NASA Research Compressor", Paper FEDSM2003-45607, 2003 Fluids Engineering Division Summer Meeting, Honolulu, Hawaii, 2003; also NASA/CR-2003-212489, 2003.

12. Lepicovsky, Jan.: "Measurements with a Split-Fiber Probe in Complex Unsteady Flows", Paper ASME GT-2004-53954, ASME IGTI Turbo Expo Meeting 2004, Vienna, Austria, 2004; also NASA/CR-2004213065, 2004.

13. Lepicovsky, Jan.: "Effects of Transducer Installation on Unsteady Pressure measurements on Oscillating Blades", Paper ASME GT-2005-69000, ASME IGTI Turbo Expo Meeting 2005, Reno, Nevada, 2005. 


\begin{tabular}{|c|c|c|}
\hline \multicolumn{2}{|c|}{ REPORT DOCUMENTATION PAGE } & $\begin{array}{l}\text { Form Approved } \\
\text { OMB No. 0704-0188 }\end{array}$ \\
\hline \multicolumn{3}{|c|}{$\begin{array}{l}\text { Public reporting burden for this collection of information is estimated to average } 1 \text { hour per response, including the time for reviewing instructions, searching existing data sources } \\
\text { gathering and maintaining the data needed, and completing and reviewing the collection of information. Send comments regarding this burden estimate or any other aspect of thi } \\
\text { collection of information, including suggestions for reducing this burden, to Washington Headquarters Services, Directorate for Information Operations and Reports, } 1215 \text { Jefferson } \\
\text { Davis Highway, Suite 1204, Arlington, VA 22202-4302, and to the Office of Management and Budget, Paperwork Reduction Project (0704-0188), Washington, DC 20503. }\end{array}$} \\
\hline 1. AGENCY USE ONLY (Leave blank) & \begin{tabular}{|c|c|} 
2. REPORT DATE & 3. \\
June 2006 &
\end{tabular} & $\begin{array}{l}\text { D DATES COVERED } \\
\text { echnical Memorandum }\end{array}$ \\
\hline \multicolumn{2}{|c|}{$\begin{array}{l}\text { Measurement of Flow Pattern Within a Rotating Stall Cell in an Axial } \\
\text { Compressor }\end{array}$} & \multirow{2}{*}{ WBS 56158.02.08.03.02.05 } \\
\hline \multicolumn{2}{|c|}{$\begin{array}{l}\text { 6. AUTHOR(S) } \\
\text { Jan Lepicovsky and Edward P. Braunscheidel }\end{array}$} & \\
\hline $\begin{array}{l}\text { 9. SPONSORING/MONITORING AGEI } \\
\text { National Aeronautics and Sp } \\
\text { Washington, DC 20546-00 }\end{array}$ & $\begin{array}{l}\text { NAME(S) AND ADDRESS(ES) } \\
\text { Administration }\end{array}$ & $\begin{array}{l}\text { 10. SPONSORING/MONITORING } \\
\text { AGENCY REPORT NUMBER } \\
\text { NASA TM-2006-214270 } \\
\text { GT-2006-91209 }\end{array}$ \\
\hline
\end{tabular}

11. SUPPLEMENTARY NOTES

Prepared for Turbo Expo 2006, sponsored by the American Society of Mechanical Engineers, Barcelona, Spain, May 8-11, 2006. Jan Lepicovsky, QSS Group, Inc., 21000 Brookpark Road, Cleveland, Ohio 44135.

Edward P. Braunscheidel, NASA Glenn Research Center. Responsible person Jan Lepicovsky, organization code RTC, 216-433-1402.

12a. DISTRIBUTION/AVAILABILITY STATEMENT 12b. DISTRIBUTION CODE

Unclassified - Unlimited

Subject Categories: 02, 07, and 35

Available electronically at http://gltrs.grc.nasa.gov

This publication is available from the NASA Center for AeroSpace Information, 301-621-0390.

13. ABSTRACT (Maximum 200 words)

Effective active control of rotating stall in axial compressors requires detailed understanding of flow instabilities associated with this compressor regime. Newly designed miniature high frequency response total and static pressure probes as well as commercial thermoanemometric probes are suitable tools for this task. However, during the rotating stall cycle the probes are subjected to flow direction changes that are far larger than the range of probe incidence acceptance, and therefore probe data without a proper correction would misrepresent unsteady variations of flow parameters. A methodology, based on ensemble averaging, is proposed to circumvent this problem. In this approach the ensemble averaged signals acquired for various probe setting angles are segmented, and only the sections for probe setting angles close to the actual flow angle are used for signal recombination. The methodology was verified by excellent agreement between velocity distributions obtained from pressure probe data, and data measured with thermoanemometric probes. Vector plots of unsteady flow behavior during the rotating stall regime indicate reversed flow within the rotating stall cell that spreads over to adjacent rotor blade channels. Results of this study confirmed that the NASA Low Speed Axial Compressor (LSAC) while in a rotating stall regime at rotor design speed exhibits one stall cell that rotates at a speed equal to 50.6 percent of the rotor shaft speed.

14. SUBJECT TERMS

Axial compressor; Rotating stall; Unsteady measurements

\begin{tabular}{|c|c|c|}
\hline $\begin{array}{c}\text { 17. SECURITY CLASSIFICATION } \\
\text { OF REPORT } \\
\text { Unclassified }\end{array}$ & $\begin{array}{c}\text { 18. SECURITY CLASSIFICATION } \\
\text { OF THIS PAGE } \\
\text { Unclassified }\end{array}$ & $\begin{array}{c}\text { 19. SECURITY CLASSIFICATION } \\
\text { OF ABSTRACT } \\
\text { Unclassified }\end{array}$ \\
\hline
\end{tabular}

NSN 7540-01-280-5500

\begin{tabular}{|l|l|} 
& $\begin{array}{c}15 . \text { NUMBER OF PAGES } \\
17\end{array}$ \\
\cline { 2 - 2 } & 16. PRICE CODE \\
\hline $\begin{array}{l}\text { 19. SECURITY CLASSIFICATION } \\
\text { OF ABSTRACT } \\
\text { Unclassified }\end{array}$ & 20. LIMITATION OF ABSTRACT \\
& \\
\hline
\end{tabular}

Standard Form 298 (Rev. 2-89)

Prescribed by ANSI Std. Z39-18 298-102 

